\title{
Evaluation of Hydrocarbon Potential, Quality of Source Rock Facies, and Delineating of their Depositional Environment in Mamu Formation of Anambra Basin, Nigeria
}

\author{
*MAJU-OYOVWIKOWHE, GE; MALOMI, BP \\ Department of Geology, University of Benin, Benin City. Nigeria. \\ *Corresponding Author Email: efetobore.maju@uniben.edu
}

\begin{abstract}
This investigation was carried out by collecting a total of six shale samples from two exposures of Mamu formation in Enugu and Igarra for geochemical analysis for investigation of source rock potential and environment of deposition. The values of TOC $(1.79-3.16 \mathrm{wt} \%)$ and SOM $(1450-1625 \mathrm{ppm})$ reveals that the shale of Mamu at the two locations are good - very good source rocks. The plot of hydrogen index against oxygen index and TOC against petroleum genetic potential shows both type III and IV kerogen indicating a gas prone and inert kerogen content. The values of Tmax ranges from $(390 \mathrm{Oc}-437 \mathrm{OC})$ suggesting that the source rock is immature to early thermally mature. Finally, the cross plot of TSC against TOC confirms a normal marine depositional environment for the samples collected at both locations.
\end{abstract}

\section{DOI:https://dx.doi.org/10.4314/jasem.v23i3.2}

Copyright: Copyright (C) 2019 Maju-Oyovwikowhe and Malomi. This is an open access article distributed under the Creative Commons Attribution License (CCL), which permits unrestricted use, distribution, and reproduction in any medium, provided the original work is properly cited.

Dates: Received: 03 January 2019; Revised: 19 February 2019; Accepted 22 March 2019

Keywords: Hydrocarbon Potential, Environment of Deposition, Mamu Formation, Cross Plot.

Since the discovery of oil and gas in Nigeria in the late 1950 's, the oil and gas industry has been marred by political and economic strife. With the world's aspiration being aligned with global energy needs, it becomes important to finding answers as to whether future hydrocarbon supply can keep pace with the increasing demand at a competitive price.

In Nigeria, two major basins have been found to generate hydrocarbon; the Niger Delta Basin and the Anambra Basin, with the nation being almost exclusively dependent on oil and gas production in the Niger Delta Basin thereby creating a state of unrest which has proven, to have a detrimental effect on the Nigeria economy.

It is estimated that the demand and consumption of petroleum in Nigeria grows at a rate of $12.8 \%$ annually hence, the Nigerian government has the need to step up its production by refocusing attention on the Anambra Basin as a possible source of commercial hydrocarbon. Exploration drilling in Anambra Basin has proved commercial gas and some oil reserves, since gas is no longer bad news, there is no justification for lukewarm attitude towards hydrocarbon exploration of the basin. The objective of this study is to evaluate the hydrocarbon potential, quality of source rock facies, and delineation of their depositional environment in Mamu formation of Anambra basin, Nigeria

\section{MATERIALS AND METHODS}

Description of study area: The present study area is centered within the Anambra Basin. Area of concentration is Mamu formation outcropping around Enugu (Southeast part) of Nigeria extending towards the Benin flank (lgarra).

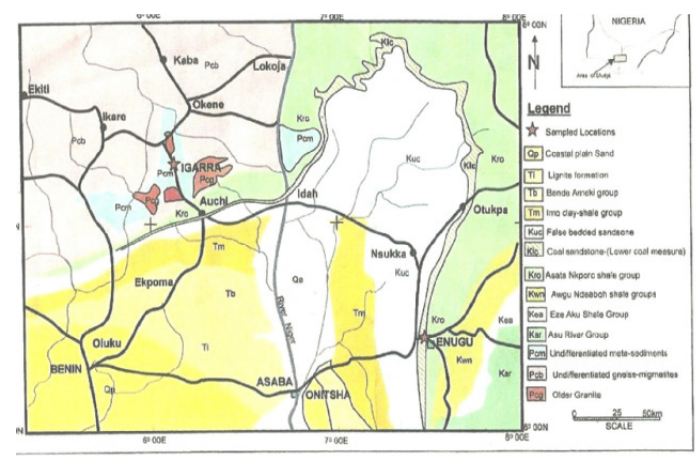

Fig 1: Geological Map Showing Sampled Locations

Stratigraphy of Anambra Basin: Different depositional environments ranging from marine to continental have been assigned to the Anambra basin by workers namely ;(Nwajide and Reijers, 1996). The basin comprises over $2000 \mathrm{~m}$ of Campanian-Maastrchtian sequence arising from cycles of transgression and regression. The base of the Anambra basin is demonstrated to overlie an important erosional surface practically a sequence boundary (Nwajide

*Corresponding Author Email: efetobore.maju@uniben.edu 
and Reijers, 1996). The succeeding regression ended in the Danian. The Anambra basin fill was deposited during one major transgression and a major regression. The major transgression in the coniancian deposited mainly shale and some sand to form the Nkporo group. Gradual subsidence and then regression in the Maastrichtian gave rise to the deposition of Deltaic forests and flood plains; Mamu, Ajali, and Nsukka formations. The building of the modern Niger Delta lithofacies was initiated by the large-scale transgression that deposited the Imo shale. The regression of the sea gave rise to deposition of the Ameki group.

Asu River Group: Sedimentation started in the lower Benue trough with the marine Albian AsuRiver group. This consists mainly of shale, fine grained micaceous sandstones and subordinate limestone. The group thickens towards the southeast and is absent in the Idah area. The average thickness is about $1800 \mathrm{~m}$ (Obaje et al, 1999). The fossils recovered from the sediments are mostly ammonites, palynomorphs, foraminifers and radiolarians. Asu river group is Albian in age and was deposited under marine conditions (Whiteman, 1982).

Eze-aku Formation: The deposition of Eze-Aku formation is associated with the beginning of the marine transgression in the lower Cenomanian (Ofodile, 1976). It consists of grey black shale, siltstone and sandy limestone. It thickens southwards with about 2000m in Owerri-Aba area.

Owelli Sandstone: The term "Owelli Sandstone" was proposed by Reyment, 1965 to replace the "Agwu sandstone". The formation consists of massive hard, ferruginous cross-bedded sandstone. The sandstone is fine-coarse grained, poorly sorted and consist of well-rounded pebbles (Agagu et al, 1985). The sandstone varies in thickness from about $213 \mathrm{~m}$ $600 \mathrm{~m}$. Its depositional environment ranges from deltaic to fluviatile (Reyment, 1965, Whiteman, 1982). Its age is Campanian-Maastrichtian (Agagu et $a l, 1985)$.

Nkporo shale: The Nkporo shale was deposited mainly in the Anambra basin and to a lesser extent in the Afikpo syncline. It consists mainly of dark greyblack shale with occasional thin beds of sandy shale. The shale is rich in microfauna, mollusc and occasional fish remains. The formation was deposited at the basal lithostratigraphic unit of the Anambra basin. The shale represents the brackish marsh and fossiliferous prodelta fades of the late Campanian-early Maastrichtian depositional Nkporo cycle (Nwajide and Reijers, 1996).On the basis of fossil, (Simpson, 1954) and (Reyment, 1965) assigned a Maastrichtian age to the formation. (Murat, 1972) assigned an upper Senonian age while (Agugu et al, 1985) assigned a Campanian to Maastrichtian age to the formation.

Mamu Formation: This information is Maastrichtian in age and it succeeds the Enugu shale without evidence of a break in sedimentation. It is referred to as the lower coal measures and consists of an alternation of fine-medium grained sandstone, darkgrey shale, mudstones, sandy shale and coal seams. The coal seams vary in thickness from $1 \mathrm{~cm}-3.5 \mathrm{~cm}$. The sediments are shallow water deposits (Cratchley and Jones, 1965). Mamu formation most probably documents a delta strand plain with thickly vegetated tidal mud flats which results in coal seams in addition to delta front sand bars, bays.

Ajali Sandstone: This overlies the Mamu formation in the Anambra basin. The formation was previously referred to as false bedded sandstone, which consists of friable well sorted whitish, fine-coarse grained and non fossiliferous sandstone is very mature and was deposited in continental sequence. The sandstone is very mature and was deposited in continental sequence. A strand plain marsh environment with occasional fluvial incursions was for this formation (Agagu et al; 1985). The thickness of the Ajali sandstone is quite variable (Simpson, 1954) gave a thickness range of $40-150 \mathrm{ft}$. Between Enugu and Ekana, the formation is $250 \mathrm{ft}$ thick.

Nsukka Formation: This overlies the Ajali Sandstone in the Anambra basin. This formation was originally regarded as being stratigraphically synonymous with the upper coal measures (Murat, 1972; Dessauvagie, 1974). The Nsukka formation proposed to replace the term upper coal measures (Reyment, 1965). The formation consists of alternations of sandstones, shales, coal. The formation was deposited under paralic conditions which prevailed during the second Post-Santonian transgressive cycle. (Simpson, 1954) suggested a Maastrichtian-Paleocene age while (Murat, 1972) Maastrichtian-Danian age for the formation.

Imo Shale: The Imo shale is mainly a fine texture, grey to bluish shale with thick sandstone bands and iron stones. The formation becomes sandier towards the top where it consists of alternation of sandstone and shale. The Imo shale grade laterally westward into the Ewekoro limestone of Dahomey Basin. The Imo shale was deposited under marine condition. The formation is about $1600 \mathrm{ft}$ thick. 
Ameki Group: The Ameki group represents the last regressive cycle of deposition within the Anambra Basin. They consist of grey-green sandy clays, sandy claystones and sandstones with its type locality in eastern Nigeria (Whiteman, 1982). It comprises of two lithological divisions: a lower division with fine to coarse sandstones with intercalations of calcareous shale and thin shelly limestone, and an upper division with coarse bended sandstone, the thickness of the formation is about 480ft. The age of the Ameki groups is Eocene (Whiteman, 1982).

Ogwashi-Asaba Formation: This formation overlies the Ameki formation and is made up of clays, sands grits and seams of lignite alternating with gritty clays. The lignite is restricted to a narrow belt within Ogwashi Deltas formation. The formation has an Oligocene-Miocene age (Dessauvagie, 1974) and it was formed within an upper flood plain environment (Allen, 1965).

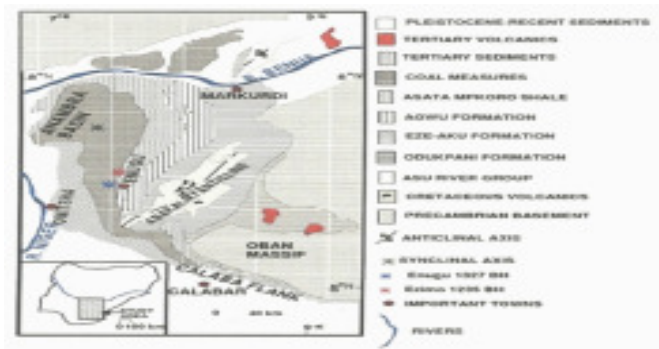

Fig: Geological map of Anambra Basin showing its stratigraphy (after Ojo et al, 2009)

Field study: Involves an initial reconnaissance survey of the area and a detailed geological mapping of the study area. It was aimed at identifying the rock types, textural characteristics and sedimentary features. The thickness and lateral extent of the outcrops were noted and photographs of the outcrops were taken. Rock samples were collected and labeled for further laboratory studies. The equipments used during the field exercise includes a base map (1:25,000), measuring tape, compass clinometers, geological hammer, hand lens, digital camera and sample bags. Others are field note book, pencil, meter rule, masking tape and marker. Study areas include fresh outcrop ofshales obtained from two different locations namely: Enugu and Igarra.

Location 1: The first location is a road cut exposure, outskirt of Auchi-Igarra town about 500m from water board. The geological unit is Mamu Formation and it is Maastrichtian in age. The rock exposure is about $2 \mathrm{~m}$ high and extends to a length of about $100 \mathrm{~m}$. The rock is bedded showing two distinct beds and within these beds are tiny lines of laminations. The rock splits easily along these lines of lamination, making it fissile. The two beds are separated by a ferrugenised hard pan. At the top of the section is a heterolith (silt and shale) with variegated colors ranging from purple, yellow reddish-brown. A ferrugenised siltstone layer, separating the top from the bottom bed. This ferrugenised siltstone layer was formed as a result of weathering and leaching away of other minerals, leaving behind a Fe-rich residue during a period of non-deposition after the bottom beds was deposited. This layer marks an erosional break in deposition, resulting in an unconformity. The bottom section constitutes a dark shale unit which is of clay size.

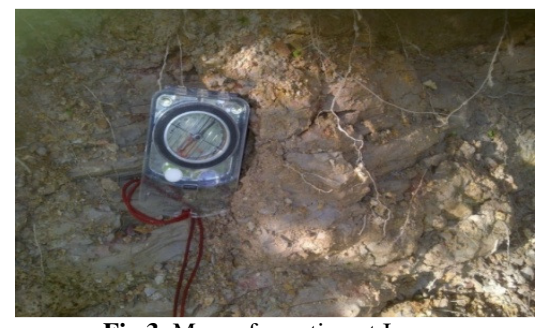

Fig 3: Mamu formation at Igarra

Location 2: This location is a road cut exposure along Enugu-Onitsha express way, $0.5 \mathrm{~km}$ from King's petrol station. The exposure is about $15 \mathrm{~m}$ high. The exposure is made up of shales, sandstone, heterolith and coal seams. The upper part of the formation is laterized obliterating the details of the sedimentary structures. The shales are black and often splintery and are interlaminated with sandstones and siltstones, rare unidentified horizontal and vertical burrows occur. Heterolith of shale and sand are dominant in the lower part of the column. They are interlaminated with well sorted very fine -fine sandstones and grey silt shale. Ripple laminations and horizontal burrows are conspicuous.

Organic geochemical analysis determination of total sulphur content (TSC): Apparatus used for this present study are platinum crucibles, electric furnace, volumetric flask (100ml capacity), water bath or hot plate. Reagents are sodium carbonate, $\mathrm{Na}_{2} \mathrm{CO}_{3}$ anhydrous, sodium nitrate, $\mathrm{NaNO}_{3}, 6 \mathrm{M} \mathrm{HCL}$ and ethanol.

Procedure: Weigh accurately $2 \mathrm{~g}$ of finely ground soil into platinum crucible; add $10 \mathrm{~g}$ of $\mathrm{Na}_{2} \mathrm{CO}_{3}$ and $0.3 \mathrm{~g}$ of $\mathrm{NaNO}_{3}$. Crucibles containing contents are put into an electric furnace and preheated with the mixtures at $400^{\circ} \mathrm{C}$ for 30 minutes, the mixture is fused at about $950 \mathrm{OoC}$, and fusion must be complete in about 10 to 20 minutes. The crucible is allowed to cool and placed in its side in a $100 \mathrm{ml}$ beaker. Enough distilled water is added to barely cover the content of the crucible and 
the beaker heated just below boiling on a stream bath or hot plate. After the melt has disintegrated thoroughly, the crucible is removed and $20 \mathrm{ml}$ of $6 \mathrm{MHCL}$ to the beaker (if there is difficult in disintegrating, add a few drops of ethanol and the acid before removing the crucible). The crucible is scrubbed and then washed with distilled water into a beaker. The content in the beaker is transferred to a $100 \mathrm{ml}$ volumetric flask after it has cooled, SO4 concentration is thus determined by turbidmetric method described before.

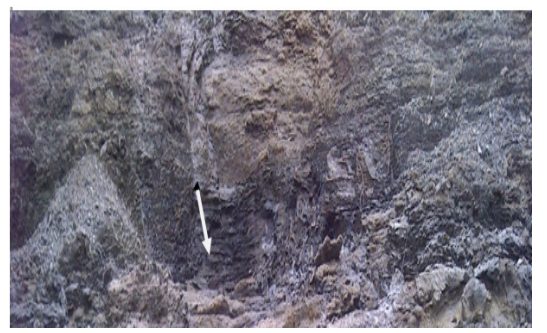

Fig 4: Road cut showing shale along Enugu- Onitsha express way

Determination of total organic carbon: 90 - 50\% of total carbon in soil is oxidized and measured by procedure. Apparatus used for this present study are burettes, 50-ml or 25-ml capacity, Erlenmeyer flask, Pipette $10 \mathrm{ml}$ capacity and automatic pipette. Reagents are; Potassium dichromate $\left(\mathrm{K}_{2} \mathrm{Cr}_{2} \mathrm{O}_{7}\right)$ in dissolved $49.04 \mathrm{~g}$ of $\mathrm{K}_{2} \mathrm{Cr}_{2} \mathrm{O}_{7}$ in distilled water and dilute to one litre, concentrated sulphuric acid $\left(\mathrm{H}_{2} \mathrm{SO}_{4}\right)$.

Procedure: Soil sample was grind to pass through $0.5 \mathrm{~mm}$ sieve, and weighed in duplicate and transferred to $250 \mathrm{ml}$ Ermeyer flask $(1.00 \mathrm{~g}$ sample should be used if the organic carbon content is between 1 and $3 \%$, and $2 \mathrm{~g}$ sample if organic carbon content is less than $1 \%$ ). $10 \mathrm{ml}$ of $\mathrm{K}_{2} \mathrm{Cr}_{2} \mathrm{O}_{7}$ solution is accurately pipette into an each flask and stirred gently to dispersed the soil. $20 \mathrm{ml}$ concentrated $\mathrm{H}_{2} \mathrm{SO}_{4}$ using an automatic pipette, directing the stream into the suspension, immediately stir the flask again and allow it to stand on a sheet of asbestos for about 30 minutes. $10 \mathrm{ml}$ of distilled water is added after standing for 30 minutes and then 2-3 drops of indicator is added and titration with $0.5 \mathrm{~N}$ ferrous sulphate solution.

Rock eval pyrolys1s: This is a technique for the anhydrous pyrolysis of source rocks that enables the chemical composition of kerogen and hence its hydrocarbon potential to be determined. The technique is also used as a maturation parameter. It does not require demineralization of samples and there is no other preparation other than pulverizing the whole rock into fine powder.

\section{RESULT AND DISCUSSION}

Thermal maturity: Thermal maturity provides an indication of the maximum paleo-temperature reached by a source rock. According to (Peters, 1986), variation in kerogen types affect $\mathrm{T}$-max of $435^{\circ} \mathrm{C}$. At thermal maturity that corresponds to a $\mathrm{T}$-max of $435^{\circ} \mathrm{C}$, source rocks with $\mathrm{HI}$ greater than 500 $\mathrm{mgHC} / \mathrm{gTOC}$ yield oil while those with HI value ranging from 250 to $500 \mathrm{mgHC} / \mathrm{gTOC}$ yield oil and some gas. Rocks with HI of 50 to $250 \mathrm{mg}$ $\mathrm{HC} / \mathrm{gTOC}$ produce gas while with HI less than 50 $\mathrm{mgHC} / \mathrm{gTOC}$ is inert. In this study, Tmax ranges from 416 to $437^{\circ} \mathrm{C}$ (426 averages) for the Mamu outcropping at Igarra, and $390-420^{\circ} \mathrm{C}$ for Mamu outcropping at Enugu axes. These values both suggest that the shales are immature to early mature source rock.

Kerogen type: Kerogen capable of generating hydrocarbons is derived from both marine and terrestrial sources. Geochemists recognize Type I, II, III, and IV kerogens, and classify these four types by optical and elemental criteria. Relatively high hydrogen contents in kerogen correspond to greater oil-generating potential. The amount of petroleum generated and expelled from a source rock increases as the atomic hydrogen-to-carbon $(\mathrm{H} / \mathrm{C})$ ratio of the organic matter increases (Hunt, 1996).In this study, the HI ranges from 64.35$93.85 \mathrm{mgHC} / \mathrm{gTOC}$ (average $79.1 \mathrm{mgHC} / \mathrm{gTOC}$ ) for Mamu formation at Igarra while HI ranges from 16.46-41.82 mgHC/gTOC (average $29.14 \mathrm{mgHC} / \mathrm{gTOC}$ ) for the Mamu formation at Enugu. As shown in the table above, the low values of $\mathrm{HI}$ in the samples obtained at Mamu outcropping at Igarra are dominated by type III kerogen which implies gas proneness, and according to (Peters, 1986) is of terrestrial origin. While the extremely low values (below $50 \mathrm{mgHC} / \mathrm{gTOC}$ ) of $\mathrm{HI}$ in the samples obtained at Mamu outcropping at Enugu indicates a type IV' kerogen which is inert, that is, it does not generate any appreciable amount of hydrocarbon (Peters, 1986).

Quantity of organic matter: As shown in the table above, the total organic content of the shale samples of Mamu formation outcropping at Igarra ranges from $2.20-3.16 w t \%$ with an average of $2.68 \mathrm{wt} \%$, while the shale samples of Mamu formation outcropping at Enugu has total organic content values ranging from $1.79-3.00 \mathrm{wt} \%$ with an average of $2.40 \mathrm{wt} \%$. These values both exceed the threshold values of $0.5 \mathrm{wt} \%$ required for a sedimentary rock to be regarded as a petroleum source rock (hunt, 1979); (Tissot and Welte, 1984). 
Table 1: Results of analysis

\begin{tabular}{|c|c|c|c|c|c|c|c|c|c|c|c|c|}
\hline $\begin{array}{l}\text { Sample } \\
\text { no. }\end{array}$ & Formation & $\begin{array}{l}\text { TOG } \\
\mathrm{Wt} \\
\%\end{array}$ & $\begin{array}{l}\text { TSC } \\
\mathrm{Wt} \\
\%\end{array}$ & $\begin{array}{l}\text { SOM } \\
\text { (ppm) }\end{array}$ & $\begin{array}{c}\mathrm{S} \\
\text { MgHC/g } \\
\text { rock) }\end{array}$ & $\begin{array}{c}\mathrm{S} \\
\text { /gHC/g } \\
\text { rock) }\end{array}$ & $\begin{array}{l}\mathrm{S} \\
\left(\mathrm{MgCO}_{2} / \mathrm{g}\right. \\
\text { rock) }\end{array}$ & Tmax & $\begin{array}{l}\text { HI } \\
\text { (MgHC/g } \\
\text { TOC) }\end{array}$ & $\begin{array}{l}\text { Ol } \\
\text { (MgHC/g } \\
\text { TOC) }\end{array}$ & PI & GI \\
\hline $\mathrm{A}$ & MAMU(Igarra) & 2.41 & 0.90 & 1520 & 0.01 & 1.57 & 1.18 & 437 & 65.2 & 49.0 & 0.02 & 1.58 \\
\hline $\mathrm{B}$ & MAMU(lgarra) & 2.30 & 0.48 & 1450 & 0.03 & 1.48 & 1.14 & 416 & 64.35 & 49.57 & 0.02 & 151 \\
\hline $\mathrm{C}$ & MAMU(lgarra) & 1.79 & 0.45 & 1462 & 0.09 & 1.68 & 1.37 & 428 & 93.85 & 76.54 & 0.05 & 1.77 \\
\hline $\mathrm{D}$ & MAMU(lgarra) & 2.29 & 0.46 & 1524 & 0.02 & 1.54 & 1.16 & 430 & 67.25 & 50.66 & 0.01 & 1.56 \\
\hline $\mathrm{E}$ & MAMU(lgarra) & 2.40 & 0.80 & 1500 & 0.06 & 1.46 & 1.39 & 420 & 60.83 & ' 57.92 & 0.04 & 1.52 \\
\hline $\mathrm{F}$ & MAMU(igarra) & 2.43 & 0.78 & 1440 & 0.023 & 1.52 & 1.35 & 435 & 62.55 & 55.55 & 0,015 & 1.543 \\
\hline A & MAMU(Enugu) & 3.16 & 0.97 & 1625 & 0.15 & 0.52 & 1.16 & 390 & 16.46 & 36.71 & 0.22 & 0.67 \\
\hline $\mathrm{B}$ & MAMU(Enugu) & 3.00 & 0.85 & 1600 & 0.15 & 0.64 & 1.43 & 405 & 21.33 & 47.67 & 0,18 & 0.79 \\
\hline $\mathrm{C}$ & MAMU(Enugu) & 2.20 & 1.20 & 1575 & 0.05 & 0.92 & 1.94 & 420 & 41.82 & 88.20 & 0.05 & 0.97 \\
\hline $\mathrm{D}$ & MAMU(Enugu) & 3.09 & 0.92 & 1620 & 0.04 & 0.52 & 1.20 & 410 & 16.83 & 38.83 & 0.07 & 0.56 \\
\hline $\mathrm{E}$ & MAMU(Enugu) & 3.11 & 0.82 & 1622 & 0.08 & 0.74 & 1.18 & 398 & 23.79 & 37.94 & 0.09 & 0.82 \\
\hline $\mathrm{F}$ & MAMU(Enugu) & 2.28 & 0.79 & 1570 & 0.12 & 0.78 & 1.53 & 400 & 34.24 & 67.11 & 1.3 & 0.9 \\
\hline
\end{tabular}

TOC $=$ Total organic carbon, TSC $=$ Total sulphur content, SOM=Soluble organic matter, $S_{1}=$ Free oil content, $S_{2}=H y d r o c a r b o n$ yield, $S 3=S 3 P e a k$, Tmax $=$ Thermal maturity, $H I=H y d r o g e n$ index, $O I=O x y g e n$ index, Reproduction index, GP=Genetic potential

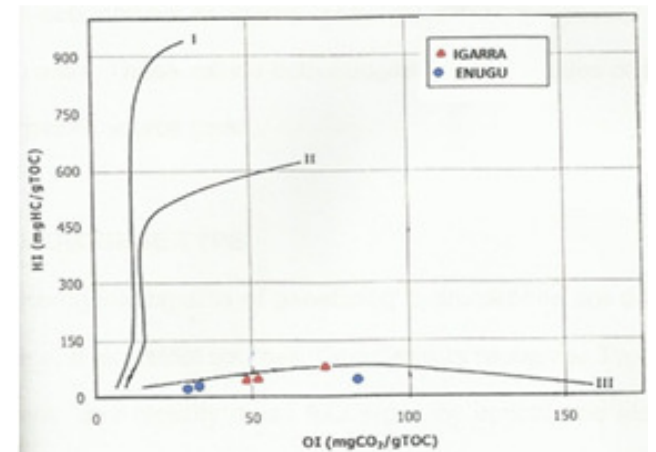

Fig 5: Plot of hydrogen index against oxygen index showing the organic matter types on the modified Van Krevelen diagram.

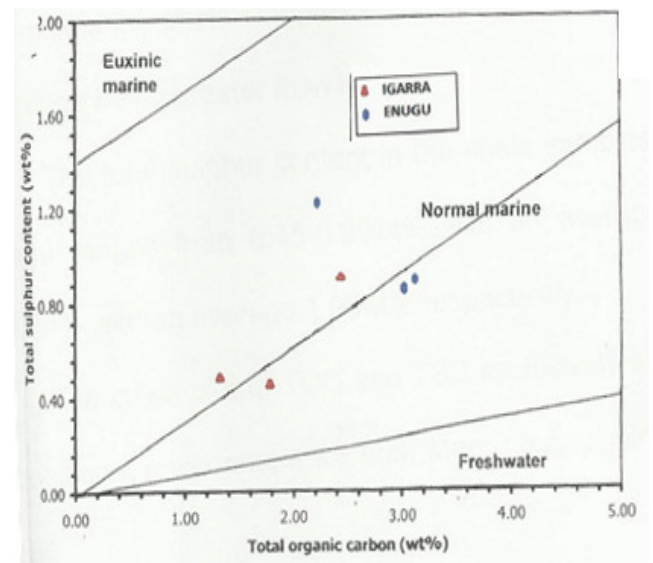

Fig 6: Plot of TSC against TOC indicating various aquatic conditions of deposition

Therefore this makes the shale samples an excellent potential-source rock based on the range being greater than two. The total sulphur content in the shale samples from both Igarra and Enugu ranges from $0.45 \sim 0.90 \mathrm{wt} \%$ with an average $0.66 \mathrm{wt} \%$ and 0.85 $1.20 \mathrm{wt} \%$ with an average $1.05 \mathrm{wt} \%$ respectively. The cross plot of TOC and TSC exclusively shows a Normal Marine depositional environment for both Mamu outcropping at Igarra and Enugu axes.

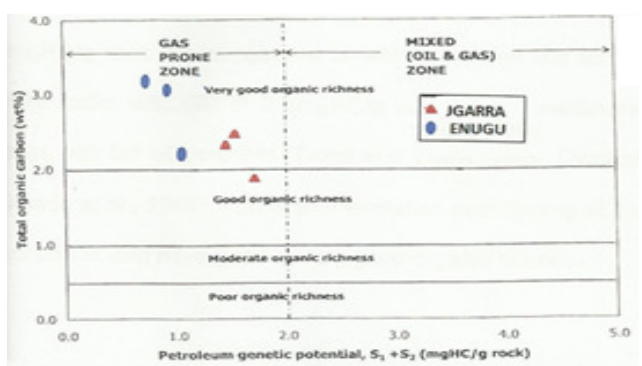

Fig 7: Plot of total organic carbon against petroleum genetic potential (modified from Akande et. Al., 2005)

Petroleum potential: Petroleum genetic potential (GP) is the sum of the 81 and 82 values obtained from Rock Eval pyrolysis. 81 provides a measure of the free oil content in a sample and accounts for the mineral in the C7-Cs2 range, excluding high molecular weight resin and asphaltane fractions which are liberated during the higher temperatures of the 82 cycle. 82 is the remaining hydrocarbon potential obtained from the cracking of kerogen. $S_{2}$ provides a measure of the potential for source rock organic matter to generate further hydrocarbons.

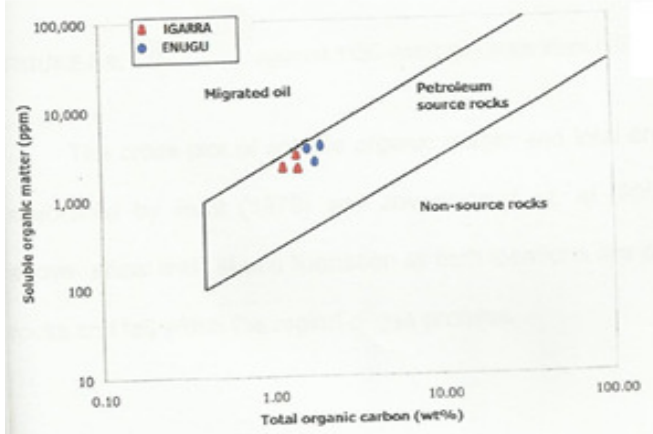

Fig 8: Plot of soluble organic matter against total organic carbon (after Jovancicevic et al., 2002).

As shown in the figure above, source rock with GP less than $2 \mathrm{mgHC} / \mathrm{g}$ rock are suggestive of infinitesimal oil but some gas potential, while rocks 
with GP of 2-6mgHC/g rock implies moderately rich source rocks with fair oil potential (Tissot and Welte, 1984); (Dymann et al., 1996); (Akande et al., 2005). The Mamu formation outcropping at both locations are gas prone; and have well to very good organic richness.

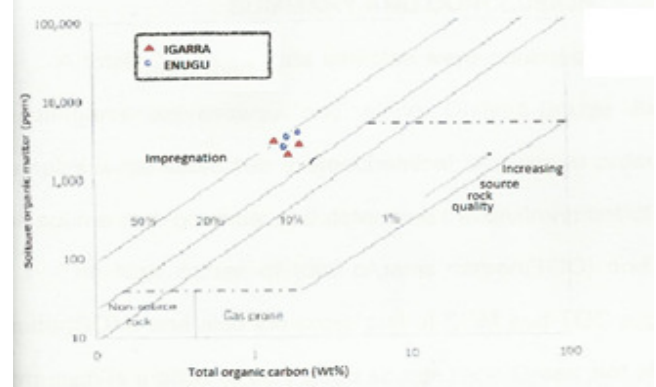

Fig 9: Plot of SOM against TOC (modified from (Hunt, 1979).

The cross plot of soluble organic matter and total organic carbon as advocated by (Hunt, 1979) and (Jovancicevicetet al, 2002). The figures above show that Mamu formation at both locations is petroleum source rocks and fall within the region of gas proness.

Conclusion: This study has been able to use existing knowledge to carry out organic geochemical studies to assess the organic matter abundance, hydrocarbon potential, maturity of source rock, as well as environment of deposition. With the world's aspiration being aligned with global energy needs, it becomes important to finding answers as to whether future hydrocarbon supply can keep pace with the increasing demand at a competitive price. Deductions from the study provided information necessary to optimize exploration activities in the Anambra Basin with a view of improving past activities in the study area.

Acknowledgment: The authors are grateful to Prof. W. O. Emofurieta for his technical and intellectual support during the course of this study.

\section{REFERENCES}

Agagu, OK, Fayose, EA, Petters, SW (1985).Stratigraphy and sedimentation in the Senonian Anambra Basin of Eastern Nigeria. J. Min. Geol. 22, 25-36.

Akande, SO, OJ, Erdtman, BD, Hetenyi, M., (2005). Paleoenvironments, organic petrology and Rock-Eval studies on source rock fades of the Lower Maastrichtian Patti Formation, southern Bida Basin, Nigeria. J. Afr. Earth Sc. 49. 394 - 406.

Allen, JRL (1965). Late Quaternary Niger Delta and adjacent areas. Amer. Assoc. Petrol. Geol. Bull.49, $547-$ 600:
Cratchley CR, Jones GP, (1965). An interpretation of the geology and gravity anomalies of the Benue Valley, Nigeria. Brit. Over. Geol. Surv., Geophysics Paper, no. $11,26 \mathrm{p}$.

Dessauvagie, TFJ, (1974). Explaratory notes to the geological map of Nigeria. J. Nig. Min. Geol. Met. Soc. 19: $1 \& 2,28$

Dymann, TS, Palacos, JG, Tysdal, RG, Perry, WJ, Pawlewicz, M J, (1996). Source rock potential of middlecretaceous rocks in southwestern Montana. AAPG Bull. 80, 1177-1184.

Hunt, JM, (1979). Petroleum geochemistry and geology. W.H. Freeman, San Francisco, 617 p.

Jovancicevic, B, Wehner, H, Scheeder, G, Stojanovic, Sainovic. A, et. al. (2002). Search for source rocks of the crude oils of the Drmno depression (southern part of the Pannonian basin, Serbia). J. Serbian Chem.Soc. 67, 553-566.

Murat, RC, (1972). Stratigraphy and paleography of the Cretaceous and lower Tertiary in southern Nigeria, in T.F.J. Dessauvagie and A.J. Whiteman, eds., African geology: Ibadan, Nigeria, Univ. Ibadan, 251-266.

Nwajide, CS, Reijers, TJA. (1996). Geology of southern Anambra Basin. In: REIJERS, TJA. (ed.). Selected chapters on geology.131-148.

Obaje, NG, Ulu, OK, Fetters, SW, (1999).Biostratigraphic and geochemical controls of hydrocarbon prospects in the Benue Trough and the Anambra Basin, Nigeria. Nig. Assoc. Petrol. Explor. Bull. 14: 1, 18-54.

Offodile, ME, (1976). The geology of the middle Benue Trough: Paleontological Institute, University of Uppsala, special publication 4, 1-166.

Peters, KE. (1986). Guidelines for evaluating petroleum source rocks using programmed pyrolysis. A.A.P.G. Bulletin, vol. 70, 318-329.

Reyment, RA, (1965). Aspects ofthe geology of Nigeria. Ibadan University Press, Ibadan, 145 p.

Simpson, A, (1954). Geology of the escarpment north of Enugu. Annual Report of Geological Survey of Nigeria, $.9-14$.

Tissot, BP, Welte, DH, (1984). Petroleum formation and occurrence, 2nd ed. Springer Verlag, Berlin, $699 p$

Whiteman, AJ, (1982). Nigeria: Its petroleum geology, resources and potential, land 2. Graham and Trottan 